Nippon Suisan Gakkaishi $\quad$ 62(4), 654-658 (1996)

\title{
坐りによる減塩かまぼこ*1の足の補強々 肪ほこ組織の電子瀕微鏡観察
}

\author{
牧之段保夫，中川孝之，安藤正史，松野 智
}

(1995年 7 月 11 日受付)

\author{
Reinforcement of Ashi (Elasticity) of Low Salt Kamaboko by Setting \\ and Observation of Kamaboko-Structure by Electron Microscope \\ Yasuo Makinodan, ${ }^{* 2}$ Takayuki Nakagawa, ${ }^{* 2}$ \\ Masashi Ando, ${ }^{* 2}$ and Satoshi Matsuno*3
}

\begin{abstract}
Ashi (elasticity) of kamaboko from white croaker Argyrosomus argentatus containing $1.5 \%$ $\mathrm{NaCl}$ in final concentration was weak as known already, but it was strengthened remarkably when the fish paste was set (or preheated) at $40^{\circ} \mathrm{C}$ for $30 \mathrm{~min}$. The ashi of thus obtained kamaboko closely resembled that of high grade kamaboko on the market, and the structure seemed to crowd when observed by electron microscope. The reinforcement effect of ash $i$ by the setting at $40^{\circ} \mathrm{C}$ for $30 \mathrm{~min}$ was hardly observed with Alaska pollack paste. However, when white croker paste was mixed to it, the effect appeared with the increase in the amount of white croker paste added. As above, it was elucidated that even if the amount of added $\mathrm{NaCl}$ is lowered to $1.5 \%$ (1.0\% if salty taste is ignored), kamaboko from white croaker or containing its meat can make strong ash $i$ if the salted paste is set at $40^{\circ} \mathrm{C}$ for $30 \mathrm{~min}$.
\end{abstract}

キーワード：坐り，隇塩，かまほこ，足，電子顕锺鏡

成人病を予防する立場から，食塩（あるいは塩化ナト リウム) の摄取量を控えようとする傾向が一般化してい る。食塩は各種の食品を通じて人体に取り込まれるた め，食品中の食塩含量はできれば空え目であることが望 屯しい。

かまほこの製造における食塩の添加は，足の形成と食 味の上で不可欠であり，市貶かまほこには約 $2.5 \%$ （終 浱度）の食塩が添加されている。しかし，最近の調査 によれば，水産ねり製品には食塩が多いとの認識が， 30〜50代の，特に女性に強いという。る゙このような認識 が広まる中で，かまほこの消費拡大をはかるためには， 減塩化は重要課題の一つであると思われる。すでにかま ほこ製造における食塩の低減化については，その一部を 程化マグネシウム等で代替でき, ${ }^{3,4}$ またシログチ肉では はとんど効果はないが，市販スケトウダラ冷涷すり身で は减塩に伴う足の低下は坐りにより補うことができると の報告がある。5,6)

本報において我々は，食塩の代替品を用いるのではな
く，坐りを用いることのみでシログチ肉を原料とする减 程かまぼこの足を補強できるかについて，かまほこ組緎 の電子䫒微鏡寉察を含めて険討した。

\section{材料および方法}

冷凍すり身 シログチ冷凍すり身は死後硬直前〜硬直 中の水蔵魚を用いて調製した。すなわち常法により得た 普通肉を $3 \mathrm{~mm}$ 目のチョッパープレートを通して細切 し，細切肉に上白糖を $5 \%$ 添加して 10 分擂潰した。す

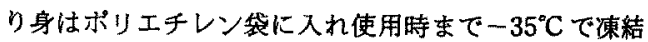
眝蔵した。スケトウダラ冾凍すり身（無塩）は株式会社 極洋より供与された $\mathrm{SA}$ 級を $-35^{\circ} \mathrm{C}$ で約 1 年間眝藏し たむのを使用した。

かまぼこの調製 冷凍すり身を $10^{\circ} \mathrm{C}$ 付近で自然解凍 後細切し，その $100 \mathrm{~g}$ をすり鉢に入れ 5 分空ずりした。 つついて蒸留水 $20 \mathrm{~g}$ と食塩（赤㯖海水株式会社製，塩 化ナトリウム合量 $99 \%$ 以上）所定量を加え 30 分擂溃 した。すり身を面ちに円简形ブラスチック容器（高さ

*1 塩の添加量を低減して作ったがぼこ。

*2 近邪大学㖘学部 (Faculty of Agriculture, Kinki University, Nakamachi, Nara 631, Japan).

*3 株式会社 極洋 (Kyokuyo, Inc., Marunouchi, Chiyoda-ku, Tokyo 100, Japan). 
$2 \mathrm{~cm}$, 直佳 $2.8 \mathrm{~cm}$, 厚さ $0.1 \mathrm{~cm})$ に詰め, 円筒の上下 両面をクレラップで包んだ後輸コムで留めた。以上の操 作は的 $10^{\circ} \mathrm{C}$ の低温室で行った。これを $90^{\circ} \mathrm{C}$ の熱水中 で 30 分，また必要に応して各温度で 30 分坐らせた後 この条件で加熱した。米水中で急冷後室温に約 1 時間 保ちかまぼこ試料とした。

足の強さの測定 ゲル強度および官能検查によった。 ゲル強度の䁚定には株式会社サン科学（東京）㹕のレオ メーターを用いた。感理軸にアダブターNo.2（球の直 佳 $7 \mathrm{~mm}$ ) を取りつけ，テーブルスピードは $0.8 \mathrm{~mm} /$ 秒 とした。試料が破断するまでの荷重（破断強度，gw） と凹みの大きさ $(\mathrm{cm})$ の皘 $(\mathrm{gw} \cdot \mathrm{cm})$ をゲル強度とし た。测定は同種かまほこ試料について6 回行い，その 平均値を求めた。な拉，厚さ $3 \mathrm{~mm}$ の試料片を用いて 行った折り曲げテスト（5 段階評価法）の結果では高い 值を示するの代多く，ゲル強度および食感と一致しなか った。このことからこのテストは足の強さの測定には用 いなかった。

透過型電子顥镜用試料作成法および観察 かまにこ 試料を約 $1 \times 1 \times 3 \mathrm{~mm}$ の大きさに切り，2.5\%グルタル アルデヒドー1\%オスミゥム酸で固定した。次に 50， $60,70,80,90,99.5,100 \%$ のタノールで各 15 分順次 脱水した後，EPOK812 に包埋した。ウルトラミクロト 一ム（MT-6000）で超博切片を作り，ウラン一鉛二重 染色後，日立一800 型電子顕铰鏡（TEM）で観察した。 走查型電子顥微鏡用試料作成法および観察 かまぼこ
試料を約 $1 \times 1 \times 3 \mathrm{~mm}$ の大きさに切り，2.5\%グルタル アルデヒドで固定した後，上と同じ条件で脱水した。次 に $\mathrm{t}$-ブタノールで圈換 $\mathrm{L}$, 真空凍結乾燥, 金蒸着を行 い，日立 S-4100 型電子顕徽鏡（SEM）で観察した。

\section{結果および考察}

食塩添加量と足の強さ 足の強いかあぼこを作るため には，すり身への食塩添加量は肉に対して $2 \%$ 以上が 必要で，これ以下では筋原阵維は溶解しないので，良い

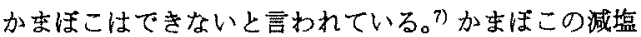
化を検討するに当たり，シログチおよびスケトウダラ冷 凍すり身（無塩）を用いて，をずこの報告を追試した。 結果を Fig. 1 の印で示す。シログヂでは食壏濃度が $2 \%$ (終澧度，以下同し。すり身の水分は約 $80 \%$ であ ったことから，できた塩化ナトリウム水溶液の濃度は約 $0.43 \mathrm{~mol} / l)$ 屯では食塩添加量が増すにつれてゲル強度 は, $200 \mathrm{gw} \cdot \mathrm{cm}(0.5 \%)$ から $733 \mathrm{gw} \cdot \mathrm{cm}(2 \%)$ まで。 急激に增加した。しかし，食塩の添加量を $3 \%$ と增加 さ忆てすゲル強度はをれほど増加しなかった（813 $\mathrm{gw} \cdot \mathrm{cm})$ 。官能的に，食塩添加量が 1.5\% 以下の製品で はかまほこ様の足は感じられなかったが，2.0\%および 3.0\%の食塩添加では，柔らかいがか心ぼ様の物性が 認められた。このような官能的評価は 3 人のパネルで 同様であり，ゲル强度による評洒と比例関係にあった。 以上のように，シログチについての結果は，以前の報告 に近いものと考えられた。一方，スケトウダラ冷凍すり

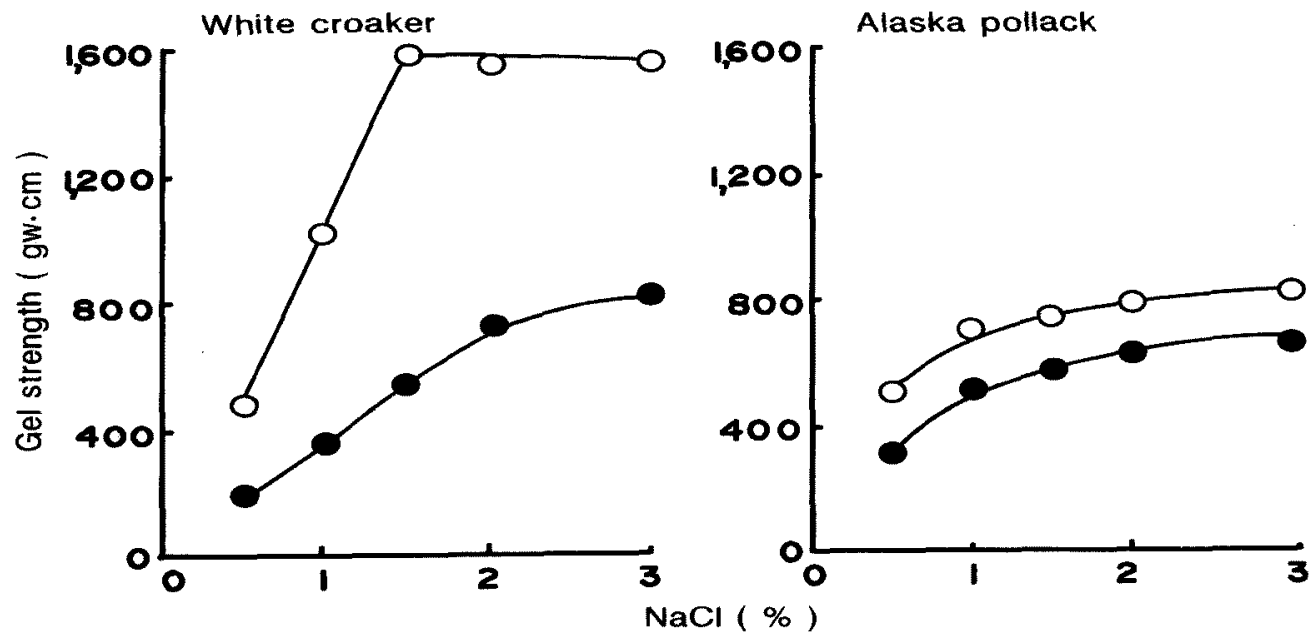

Fig. 1. Effect of the amount of added $\mathrm{NaCl}$ and setting on the gel strength of kamaboko. White croaker $A r$ gyrosomus argentatus, and Alaska pollack Theragra chalcogramma (frozen surimi) were used as material. Closed circle shows the gel strength of kamaboko heated at $90^{\circ} \mathrm{C}$ for $30 \mathrm{~min}$ without setting. Open circle shows the gel strength of kamaboko heated at $90^{\circ} \mathrm{C}$ for $30 \mathrm{~min}$ after setting at $40^{\circ} \mathrm{C}$ for $30 \mathrm{~min}$. 


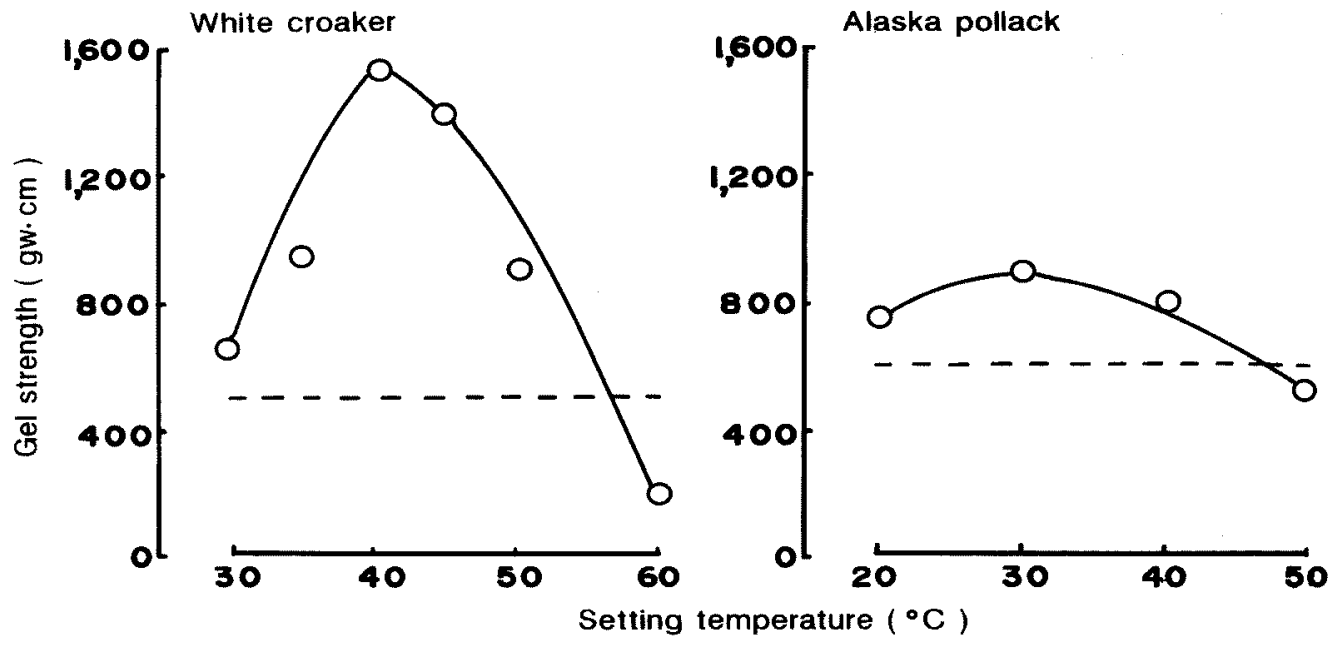

Fig. 2. Effect of setting temperature on the gel strength of kamaboko. The amount of added $\mathrm{NaCl}$ was $1.5 \%$ in final concentration. Open circle shows the gel strength of kamaboko heated at $90^{\circ} \mathrm{C}$ for $30 \mathrm{~min}$ after heated at indicated setting temperatures for $30 \mathrm{~min}$. Dotted line shows the gel strength of kamaboko heated at $90^{\circ} \mathrm{C}$ for $30 \mathrm{~min}$ without setting.

身を用いた場合には，ゲル強度に及ほす食塩濃度の影響 は少なく，3\%の食塩を添加しても強い足は形成され なかった。ただし，食塩 $0.5 \%$ 添加のものでも，シログ チの場合とは異なる，ある種の物性が認められた。おそ らく，スケトウダラ冾凍すり身に含をれている重合リン 酸塩による等原瀻維の溶解作用に基づくのであるう。

減塩かまぼこの足の補強に及ぼす坐り温度の影罯 か まぼこ製造に抢ける食塩の低隇化を考える場合，食塩の 添加量は終搌度で $2 \%$ 末満である。前項の実験で，食 塩 $1 \%$ では塩味は全く感しられす，この添加量は食味 上不適当と判断された。そこで，やや薄味ではあるが， 添加量を $1.5 \%$ として，まず足の補強に及ぼす坐り温度 の影響を調べた。Fig. 2 に示すように，シログチの場 合， $30^{\circ} \mathrm{C} \sim 50^{\circ} \mathrm{C} て ゙ 30$ 分の坐りを行ったもののゲル強度 は， $90^{\circ} \mathrm{C}$ で 30 分直加熱して得られたかまほこのゲル強 度に比へ，いす犳も強く，特にその增加は $40^{\circ} \mathrm{C}$ で影著 であった。スケトウダラでは $30^{\circ} \mathrm{C} て ゙$ 坐り効果が認めら れたが，その程度は小さかった。周知のように，この魚 の場合，坐り効果を上げるにはより長時間の放置が必要 である。

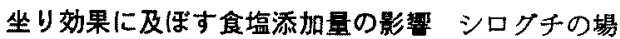
合, $40^{\circ} \mathrm{C}$ で顕著な坐り効果が垫められたので， $40^{\circ} \mathrm{C}$, 30 分の坐り効果に及ほすす食塩添加量の影響を調へた。 Fig. 1 の○印で示すように，シログチでは，食㦈添加量 が $1 \%$ で，坐りによりゲル強度は著しく增加した。 食塩 $1.5 \%$ を含むかまぼこでは，そのゲル強度は坐りを
行わないコントロール值の約 3 倍となり，食塩 $3 \%$ を 含む坐りかまほこと同等のゲル強度を示した。スケトウ ダラ冾凍すり身では，いずれの食塩濃度でむ $40^{\circ} \mathrm{C}, 30$ 分の坐りでは奻果はほとんど認められなかった。このよ うな結果は，市眅スケトウダラ冷凍すり身を用いた場 合，減塩か屯ほこの足は坐りにより強化されるが，シ口 グチ肉を用いた場合にはこの効果ははとんと認められな いとの報告6と相違した。

以上の上うにシログチの場合，食塩濃度が $1.5 \%$ でむ $40^{\circ} \mathrm{C}$ で 30 分の坐りを行うことにより，かまほこに強い 弾力を与えることができる。塩味を無視するならば，食 塩 $1 \%$ 添加でむ $40^{\circ} \mathrm{C}, 30$ 分の坐りを併用すれば弾力の あるかまぼこを作ることができる。すでに述へたよう に，足のあるかまほこを作るためには，筋原瀻維を溶解 させるために，肉に対して $2 \%$ 以上の食塩を加えて擂 溃することが必要とされている。兄し加し，本実験結果 からすると，シログチかまほこの足形成そのむのには， 少なくとも坐りを行えば，そのような多量の食塩の添加 は必要でなく，さらに筋原鐵維の十分な溶解仗かならす しむ必要ではなさそうに思われる。

混合すり身を用いたかすばこの足の補強に及隹す坐り の影響 かまほこの製造ではしばしば 2 種以上の魚肉 が混合される。Fig. 3 はシログチおよびスケトウダラの 混合すり身に，食塩を $1.5 \%$ 涯加して作ったかまぼこの ゲル強度の增加に及ほす $40^{\circ} \mathrm{C}, 30$ 分の坐りの影響を調 べた結果である。すでに示したように，スケトウダラ肉 


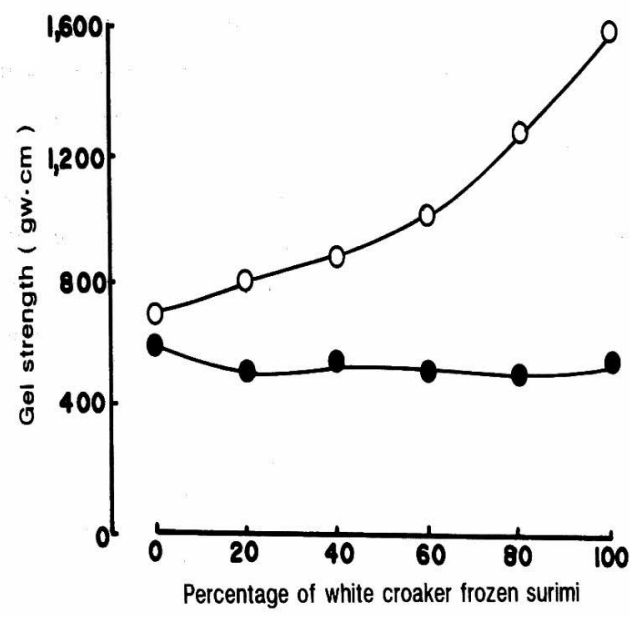

Fig. 3. Effect of setting on the gel strength of kamaboko made of mixed surimi. Mixed surimi containing $1.5 \% \mathrm{NaCl}$ in final concentration was heated at $90^{\circ} \mathrm{C}$ for $30 \mathrm{~min}$ without setting (•) or after setting at $40^{\circ} \mathrm{C}$ for $30 \mathrm{~min}(\mathrm{O})$. Frozen surimi of white croaker and Alaska pollack were mixed as shown in the axis of abscissa.

のみではこの坐りによる足の補強効果は認められなかっ たが，スケトウダラ肉にシログチ肉を混合することによ り，シログチ肉量に比例して明らかな効果が認められ た。このように, シログチ肉を含む混合すり身を用いた 場合でも，かまぼこの減塩化は可能である。

以上のように，减塩すり身です坐りを行えばゲル強度 の強いかまほこを作ることができる。たたし，かまほこ の足の質はゲル強度では適正に示すことができず，むし ろ破断強度と破断凹みのバランスをみる必要があるとい う指摘もある。采ここまでの実験に供したかまほこにつ いて両者の関係を示すと Fig. 4 のとおりである。なお, ここには参考のために 3 種の市販品についての值む示 してある。市販品 B，C は筆者らの官能試験によれば, 優れた食感を示し，またいすれれ全国蒲鉾品評会で水産 庁長官賞を受賞した製品である。このことから，かまほ この足の質は $\mathrm{B}$ 点と $\mathrm{C}$ 点とを結んだ直線の, B 点と $\mathrm{C}$ 点に近い值を示すむのほど良質と考えてよさそうであ る。この仮定からすると, Fig. 4 に示すとおり，食塩濃 度が $1.5 \%$ の減塩製品でも $40^{\circ} \mathrm{C}, 30$ 分の坐りを行った シログチかまぼこの足は, 破断強度がやや強かったが, かなり良質と考えられる。

かまぼこ組織の観察 以上のかまぼこの組織を電子顕 钽鏡（電影）を用いて観察した。Fig. 5 および 6 は透過 型電影像である。食塩濃度 $1.5 \%$ のかまぼこ（ゲル強度 $570 \mathrm{gw} \cdot \mathrm{cm}$ ) の組織（Fig. 5-2）は, 同 $3 \%$ のかほ

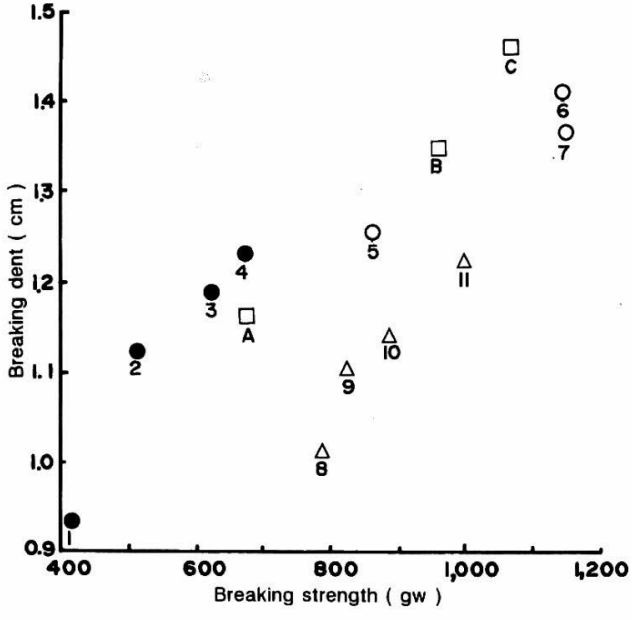

Fig. 4. Comparison of the breaking strength and the breaking dent of various kamabokos. Numbers $1,2,3$, and 4 show kamaboko from white croaker containing $\mathrm{NaCl}$ of $1,1.5,2.0$, and $3.0 \%$ without setting, respectively. Numbers 5 , 6 , and 7 show kamaboko from white croaker containing $\mathrm{NaCl}$ of $1.0,1.5$, and $3.0 \%$ with setting, respectively. Numbers $8,9,10$, and 11 show kamaboko from mixed surimi containing white croaker of $20 \%$ and Alaska pollack of $80 \%(20: 80), 40: 60,60: 40$, and $80: 20$, respectively. A, B, and C show kamaboko A, B, and $\mathrm{C}$, on the market, respectively.

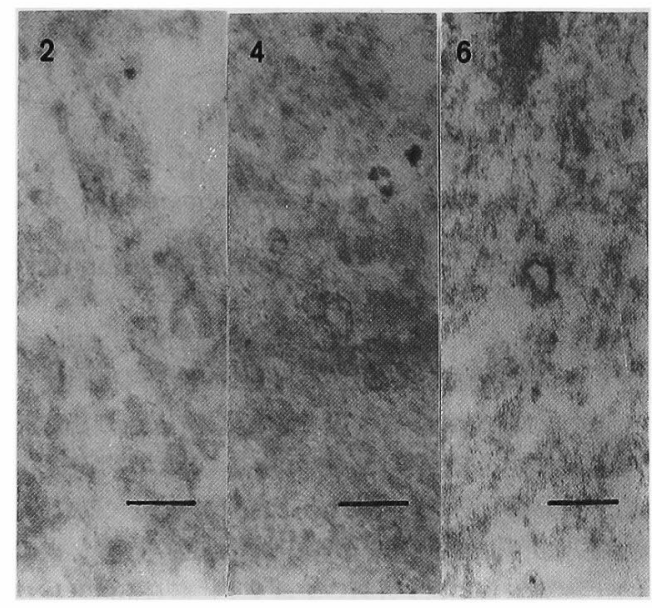

Fig. 5. Transmission electron micrographs of kamaboko from white croaker. Numbers show the same ones as in Fig. 4. Bars represent 0.2 $\mu \mathrm{m}$. 


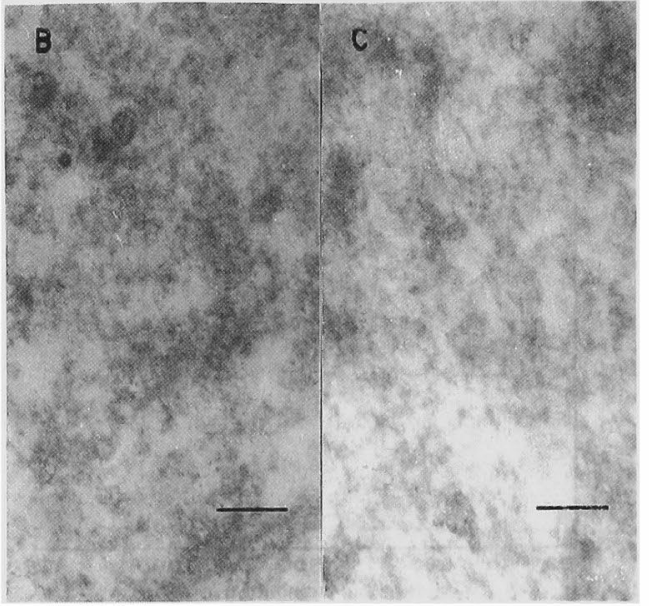

Fig. 6. Transmission electron micrographs of kamabokos on the market. $\mathrm{B}$ and $\mathrm{C}$ show kamabokos $\mathrm{B}$ and $\mathrm{C}$ on the market, respectively. Bars represent $0.2 \mu \mathrm{m}$.

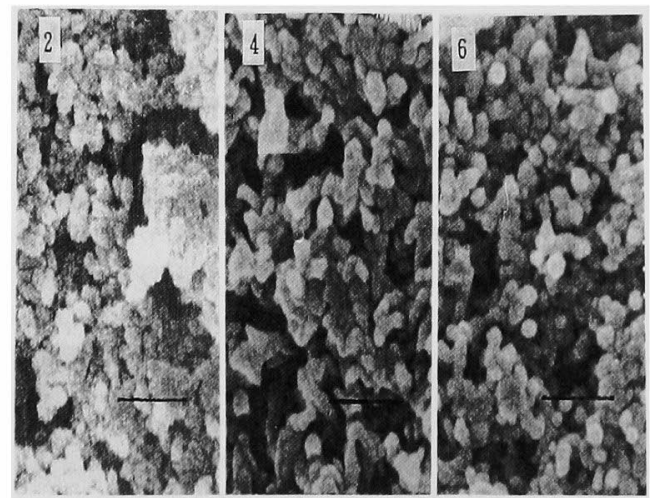

Fig. 7. Scanning electron micrographs of kamabokos from white croaker. Numbers show the same ones as in Fig. 4. Bars represent 0.2 $\mu \mathrm{m}$.

こ（ゲル強度 $813 \mathrm{gw} \cdot \mathrm{cm} ）$ の組織（Fig. 5-4）に比べ て，タンパク質（フィラメント）凝集体の分散状態が粗

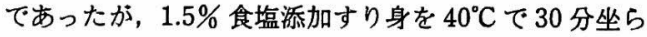
せたもの（ゲル強度 $1,600 \mathrm{gw} ・ \mathrm{~cm} ）$ では密となるよう であった (Fig. 5-6)。足の強いかまほこでは, タンパ ク質の分散状態が密となることはすでに明らかにされて いる。9,10) たたし，本実験においては，1.5\% 食塩添加坐 クかまほこのゲル強度は $3.0 \%$ 食塩添加直加熱かまほこ のそれよりむはるかに大であったが，それらの組織像 (Fig. 5-6 と Fig. 5-4) にはこのような関係は認められ なかった。参考までに，市販かまぼこの電䫓像を示すと
Fig. 6 のとおりである。タンパク質凝集体の分散状態は 比較的密であった。なお，すり身の調製はすり鉢とすり こぎよったが，筋原緘維の残存 ${ }^{11)}$ は観察されなかっ た。

Fig. 7 は走査型電顕像である。各突起はフィラメント の凝集体と考えられる。その直径（30 個の平均値士標 準偏差）は，1.5\% 食塩添加直加熱かまぼこ（Fig. 7-2） で $48 \pm 7.2 \mathrm{~nm}, 40^{\circ} \mathrm{C}$ で 30 分の坐りを行ったもの（Fig. 7-6）では $44 \pm 7.7 \mathrm{~nm}$ であり，明らかな差異は認めら れなかった。坐りによりフィラメントの分散性は良くな るほか，それは太くなるようであるという報告むある が,12)本実験結果では，足の強さにはフィラメントの太 さよりはそれらの分散状態あるいは網目構造の発達がよ り関係しているのではないかと考えられる。参考までに 3\% 食塩添加かまほここの電影像を示すと Fig. 7-4のと おりで, フィラメント凝集体の直径は $50 \pm 9.7 \mathrm{~nm}$ であ った。

以上のように，食塩添加量（終濃度）を $1.5 \%$ （塩味 を無視するならば $1 \%$ ）と低減したシログチすり身で む， $40^{\circ} \mathrm{C}$ で 30 分の坐りを行うことにより，組織的にも 密で，良質な足を持つかをほこを作り得ることが明らか になった。

\section{文献}

1）山崎小万: 図説 食品成分表（科学技術庁資源調査会編） 一橋出版，東京, 1993, pp. 84-85.

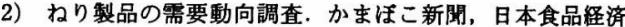
社, 東京, 1995, pp. 2-3.

3）福田耕一，野崎征宜，田端義明：かまほこ製造における 減塩化について，水産ねり製品技術研究会誌，14，394402 (1989).

4）岡 弘康，二宮順一郎，大野一七：减塩シャコ天ふらの 品算改善に関寸る研究．水産就り製品技術研究会誌，18， 13-21 (1992).

5）水上 広，山本常治：減塩かまほこならびに無塩かむほ こ製造に関する試験 (2)，水産水り製品技術研究会誌， 7 , 305-310 (1982).

6）山本常治 : 低塩湿度領域に於ける坐りならびにかまほこ 形成能について，水産小り製品技術研究会誌，8，489496 (1983).

7）志水 寛：和り製品，「水産加工技術」(太田冬雄編)，但 星社厚生閣, 東京, 1991, pp. 128-143.

8）山本常治 : 市肘板付蒲鉾の弾力につつて．本産ねり製品 技術研究会誌, 12, 209-212 (1986).

9）三宅正人，林 孝市郎，田中明子，丹羽栄二：加活こ における筋原䄉稚の分散状態に関する電子顕微鏡稓察 水誌, 37, 534-539 (1971).

10）丹羽栄二：坐り，「魚肉和り製品一研究と技術」（志水 寬稐), 恒星社厚生閣, 東京, 1984, pp. 25-35

11）佐藤繁雄，土屋隆英，松本重一郎：かまほここ微細構造 の電子顕微鏡による観察. 日水誌，50, 1869-1876 (1984).

12）佐藤繁雄, 中川則和, 土屋隆英, 松本重一郎：加活 の調製過程の電子䫒微鏡による解析. 日水誌, 53,649 658 (1987). 